\title{
Specific Indicators of the Government Bodies' ctivities Effectiveness as an Element of the Mechanism for Fighting Corruption
}

\author{
Daria A. Andreeva* \\ International Banking Institute \\ 60 Nevsky Pr., St. Petersburg, 191023, Russia
}

Received 24.11.2015, received in revised form 08.12.2015, accepted 14.01.2016

The research paper presents the analysis of methodology for assessing the effectiveness of activities of the executive authorities of the Russian Federation exemplified by activity of the Committee for Social Policy of St. Petersburg. The key performance indicators of the civil servants' activity from the Committee for Social Policy of St. Petersburg, proposed by the author, allow evaluating the effectiveness of the civil servant's activity. The prospects for applying this methodology as one of the ways for fighting corruption in this government bodies are considered.

Keywords: civil servants, corruption, key performance indicators.

DOI: 10.17516/1997-1370-2016-9-2-501-509.

Research area: economics

\section{Introduction}

The presence of corruption in government has never been regarded as a serious problem, and it has not been paid as careful attention as in the recent time. The government is seriously concerned about this issue and is full of determination to fight corruption. Corruption prevention is closely connected with the necessity to improve the effectiveness of the executive authorities' activity.

The major purpose of all the extensive reforms in the sphere of civil service conducted for the last 20 years both abroad and in Russia has been to increase the effectiveness of the executive bodies' activities and the quality of their functions and public services provided. The activity cannot be characterized as an effective one meanwhile there is a corruption element in it. "Person-toperson" relationships are particularly sensitive area for the possibility of corruption behaviour in one form or another.

The index of civil service effectiveness in Russia is still relatively low, while the corruption level in the government agencies has become incredibly high.

\section{Statement of the problem}

The sphere of public services mostly suffers from corruption. However, legislation transformation alone will not be able to stop the spread of corruption. Initiating numerous criminal cases, the Investigative Committee of the

(C) Siberian Federal University. All rights reserved

* Corresponding author E-mail address: a.d.andreeva@yandex.ru 
Russian Federation only removes the symptoms (Korruptsionnye..., 2015). New, more informed and disingenuous officials come after those, who were subjected to punishment. The new laws do not have enough time to be put into effect as legal methods to avoid them are developed.

Changes in legislation and statutory framework that regulate the authorities' activities as well as reducing the number of officials will not eradicate the problem. According to G. Malenkov's words: “Officials are like jackdaws on wires. When scared away, they would fly up, around and sit down on other wires." We need an effective system of control and reporting on the activities conducted not only of a particular government agency on the whole, but every department and every employee as well.

Despite the importance and relevance of the topic it is practically not developed in the Russia's doctrine. The methodology of the public service institutional environment evaluation was the subject of study conducted by the World Bank (Based on the..., 2000). Studies on preventing corruption in government bodies (Broadman, Recanatini, 2000) were conducted separately. D. Kaufmann, A. Kraay and M. Mastruzzi (2005) mention the rule of law, government effectiveness and fighting corruption (Kaufmann, Kraay, Mastruzzi, 2005) among the six performance indicators.

Thenecessity to developasystem ofindicators and criteria for assessing the performance of executive bodies and their officials is obvious. The author proposes a system of assessment exemplified by the activity of the Committee for Social Policy of St. Petersburg.

\section{Discussion}

There is a methodology for assessing effectiveness of the executive bodies' activity (5). The main goal of the methodology is evaluating the effectiveness of executive authorities' activity in terms of efficiency of the budgetary funds spending, the dynamics of changes in the indexes of the level of living, social and economic development of the region, as well as the degree of implementing the methods and principles of management that provide transition to the more effective models of regional governance. The results of such an assessment allow to identify the zones which require priority attention of the local authorities and to make an action list to increase the effectiveness of the regional executive bodies' activity (Andreeva, 2015). The official data, presented in the reports of the high ranking officials from the subjects of the Russian Federation, official statistics of the Federal State Statistics Service, the data of department statistics and the results of public opinion polls, are used as initial data.

Regardless the fact that the methodology used includes a large number of criteria, it cannot be applied to evaluate the effectiveness of a particular government body activity. It is universal for all institutions and does not take into account the specific features of activity of the Committee for Social Policy of St. Petersburg. Besides, the indexes are calculated at the regional level. Indexes obtained using the methodology are of little value for assessing the effectiveness of the Committee activity and its employees, and do not provide information about the presence/absence of corrupt behavior of its employees.

The need to develop indexes that characterize the effectiveness of a particular body activity the Committee, is evident. In order to select the indexes that characterize efficiency of the Committee's activity, first, it is necessary to select targets the Committee activity is directly aimed at. These targets are given in Fig. 1.

The suggested activity effectiveness assessment system of the Committee for Social 


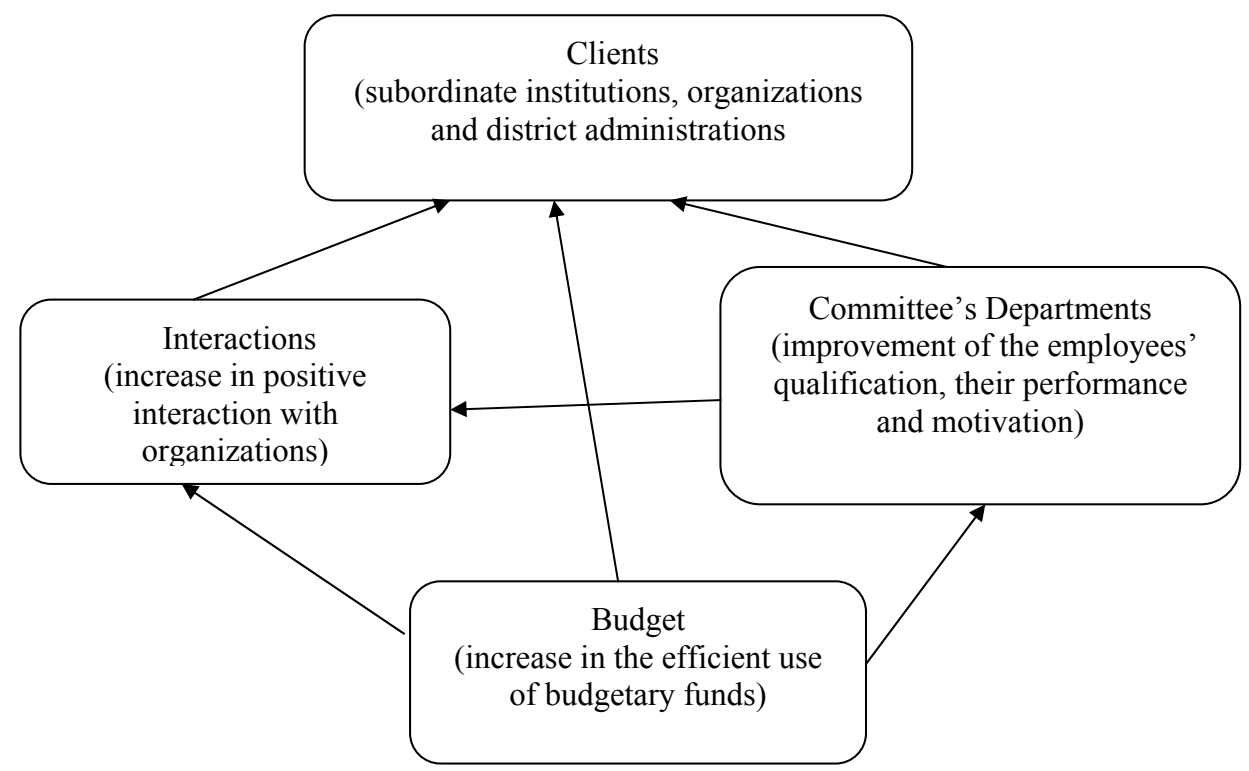

Fig. 1. The model of targets of the activity of the Committee for Social Policy of St. Petersburg

Table 1. The principles of creating the system of indicators for assessing the activities of the Committee for Social Policies of St. Petersburg

\begin{tabular}{|l|l|}
\hline \multicolumn{1}{|c|}{ Principle } & \multicolumn{1}{c|}{ Clarification } \\
\hline Interrelationship & Direct relationship to the goals and objectives defined by the Committee \\
\hline $\begin{array}{l}\text { Clarity and unambiguity, } \\
\text { ease of understanding } \\
\text { and simplicity of use }\end{array}$ & $\begin{array}{l}\text { To ensure the possibility of collection and comparison of data the indicator } \\
\text { should be clearly defined; from the indicator definition it should be clear whether } \\
\text { an increase in its value shows the improvement of its position with the service } \\
\text { provision }\end{array}$ \\
\hline Comparability & $\begin{array}{l}\text { The indicators are supposed to ensure comparability over time and allow to } \\
\text { compare committees }\end{array}$ \\
\hline Verifiability & The values (collected and calculated data) can be checked \\
\hline Statistical reliability & The indicators are supposed to be based on the reliable systems of data collection \\
\hline Economic feasibility & $\begin{array}{l}\text { It is important to keep reasonable balance between the cost of data collection and } \\
\text { the utility of these data }\end{array}$ \\
\hline Responsiveness & Indicators should quickly respond to changes \\
\hline $\begin{array}{l}\text { Flexibility towards } \\
\text { innovations }\end{array}$ & Certain indicators system shouldn't prevent innovative activity \\
\hline
\end{tabular}

Policy of St. Petersburg includes three groups of indicators: indicators of direct results; customer satisfaction and indicators of assessment of the efficient use of budgetary funds.

The principles of formation of the system of indicators are given in Table 1 (Kholostova, 2013).
The system of performance indicators and effectiveness of the Committee's activity, as well as the author's proposals for its modernization are given in Table 2.

The Gini index and the coefficient of funds, calculated for all the districts of St. Petersburg, allow to rank the districts of Saint Petersburg 
Table 2. Indicators added to the existing methodology for assessing activity of the Committee for Social Policy of St. Petersburg.

\begin{tabular}{|l|l|}
\hline \multicolumn{1}{|c|}{ Group of indicators } & \multicolumn{1}{c|}{ Estimate indicators } \\
\hline \multirow{4}{*}{ Indicators of direct result } & Growth in the quality of life / Costs for achieving it \\
\cline { 2 - 3 } & The Gini coefficient (calculated for districts) \\
\cline { 2 - 3 } & Coefficient of funds (calculated for districts) \\
\cline { 2 - 3 } & The dynamics of the efficient use of budgetary funds for specific programmers \\
\hline Customer satisfaction & Customer satisfaction index \\
\hline Indicators of direct processes & $\begin{array}{l}\text { Efficiency of the employees performance by functional / Expenses for } \\
\text { employees }\end{array}$ \\
\hline
\end{tabular}

according to the level and quality of living and to point out the districts which residents need more social support and, consequently, it would possible to allocate the budget according to the principle of priority.

Customer satisfaction index might be calculated on the basis of questionnaires about the quality of the Committee's services that are supposed to be filled in anonymously in the administrations, organizations under jurisdiction or budgetary organizations. This minimizes the possibility of obtaining misleading and falsified data about the body's activity.

Based on the data available it is possible to calculate effectiveness of the Committee for Social Policy.

$\mathrm{E}=\frac{\text { results }}{\text { spendings }}=\frac{\Delta \mathrm{I} \text { L.C. }}{\Delta \text { budget on social policy }}$,

where E - effectiveness of the Committee's activity;

$\Delta$ I L.C. - change in the index of the quality of life;

$\Delta$ budget on social policy - changes in the amount of budget for social policy implementation in index measurement.

$I_{\text {L.C. }}=I_{1} * I_{2} * \ldots \ldots * I_{i}$,
$I_{i}$ - index point of activity in a certain sphere of social policy.

$I=\frac{D_{\text {fact }}-D_{\min }}{D_{\max }-D_{\min }}$,

I - index of a given type;

$D_{\text {fact }}$ - factual indicator value;

$D_{\min }$ - indicator value taken as minimum;

$D_{\max }$ - indicator value taken as maximum .

The use of objective statistical data, independent from the opinions of the body's employees, minimizes the possibility of corruption acts. The values are impossible to overstate by the Committee employees due to transition to the automatized system of documents circulation "electronic document management system".

Assessment system of the Committee's activity effectiveness should be connected with the assessment system of the stuff activity effectiveness. Effectiveness of the social services activity should be provided by the specialists who have professional education that comply with the requirements and nature of the work done, experience in the field of social services and personal qualities for the social services provision. In the author's opinion, monitoring of a particular member of staff activity will contribute to the reduction of corrupt practices.

Currently, there are no methods, clear criteria, indicators and procedures for assessing 
the effectiveness of civil servants. The practice of HR units is dominated by a narrow view of efficiency and performance assessment, there are no analytical units, which could analyze and evaluate the effectiveness of the civil servants activity and were not interested in high performance indicators. In most cases assessment is carried out only in the form of certification (Statute on..., 2005), almost entirely based on formal indicators and not objective. Such activity efficiency assessment system is perceived by the civil servants as a mere formality and in practice does not affect their salaries.

The author suggests introducing a comprehensive system for assessing efficiency of the civil servants' performance.

Let us illustrate it through the example of the department of analysis and development forecasting. Criteria for assessing the effectiveness of the department employees are determined by the specific character of their activities. Civil servants conduct forecasting, planning, solutions development, control, surveillance and other functions which are included in implementation of all the stages of management process. Based on the major task of administration, civil servants carry out strategic, social, financial, communicative and registration common functions. Specific functions that are directly performed by the government officers result from the common functions.

To raise assessment objectivity it is necessary to develop particular criteria for assessing the performance of the department and its employees. For the criteria development the author suggests to use Key Performance Indicators methodology (KPI) (Parmenter, 2007).

KPI (Key Performance Indicators) are indicators that show how effectively the Committee for Social Policy of Saint Petersburg, in particular the department of analysis and development forecasting, moves towards its goals and objectives achievements. This is a kind of the Committee and of all its subdivisions' strategy picture, which main feature is the presence of an individual indicator for each civil servant effectiveness indicator, measured and considered in conjunction with KPI of the whole Committee. The purpose of the system is to coordinate the work of all the subdivisions of the Committee, to exclude the possibility of the obtained data falsification or indicators overstatement. Each specialist works for a common purpose and gets bonuses for the effective fulfillment of the tasks set. This excludes the possibility of corrupt behavior when performing direct official duties, since there is an anonymous evaluation of the employees' activity.

Within the framework of development of the executive bodies' effectiveness assessment system the activity effectiveness assessment algorithm for the department of analysis and development forecasting is considered (Fig. 2).

In accordance with the algorithm above, a step-by-step analysis of activity of the department of analysis and development forecasting is conducted; its goals and objectives are being defined. Criteria for assessing the activity of the department of analysis and development forecasting are developed. All the employees of the department are divided into two categories: "experts" (the chief specialist and the leading specialist) and "managers" (the head of the department). The goals and objectives of the department's employees are the same and they also coincide with the goals and objectives of the department. The employees' functions differ only in the extent of responsibility for their fulfillment.

The criteria and the indicators of the department's activity effectiveness assessment are given in Table 3. The proposed criteria are universal and suiTable for effectiveness assessment of not only of the department of 


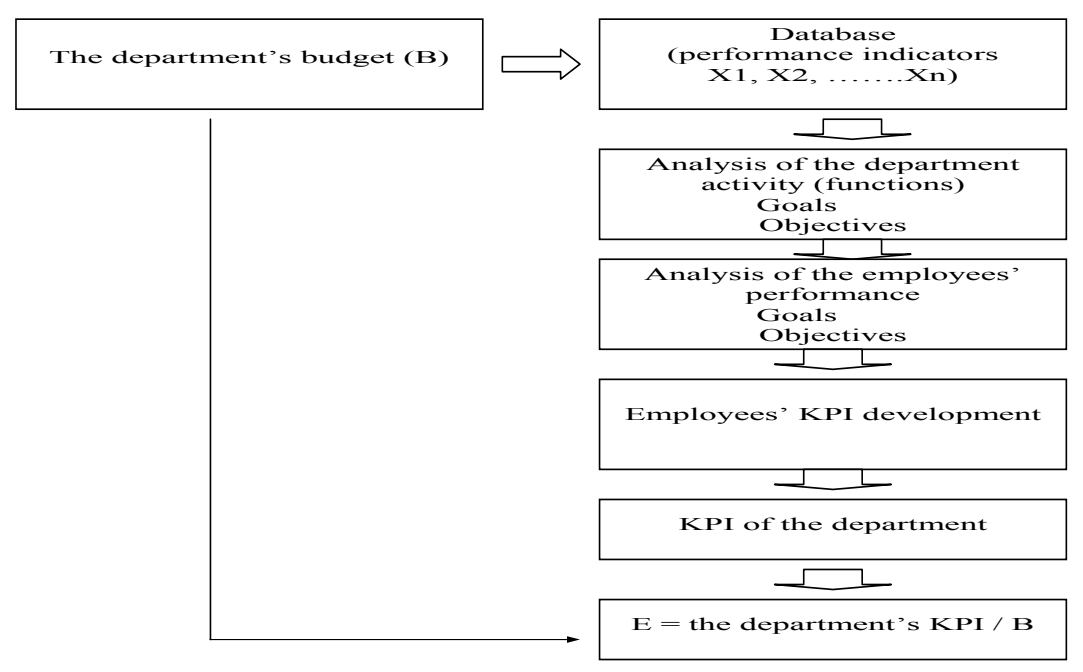

Fig. 2. The algorithm for assessing effectiveness of the department's performance

Table 3. Criteria for the department's activity assessment

\begin{tabular}{|l|l|l|}
\hline Name of criterion & \multicolumn{1}{|c|}{ The essence of criterion } & \multicolumn{1}{|c|}{ Indicator } \\
\hline $\begin{array}{l}\text { The degree of } \\
\text { decisions and } \\
\text { actions' legitimacy }\end{array}$ & $\begin{array}{l}\text { The criterion can be regarded as universal; observance } \\
\text { of laws gives order and purposefulness to government } \\
\text { administration; any violations of the principle of legitimacy, } \\
\text { regardless of their grounds, cannot be considered as } \\
\text { effective from the points of view of society and public } \\
\text { administration; all the decisions and actions of public } \\
\text { officials should totally comply with legislation and } \\
\text { regulatory legal acts of the Russian Federation }\end{array}$ & $\begin{array}{l}\text { The number of } \\
\text { reclamations (complains) } \\
\text { from the citizens and } \\
\text { organizations about } \\
\text { illegitimacy and } \\
\text { illegality of public } \\
\text { officials' actions }\end{array}$ \\
\hline $\begin{array}{l}\text { Discipline } \\
\text { leservance (the high } \\
\text { level of executive } \\
\text { discipline) }\end{array}$ & $\begin{array}{l}\text { This is the assessment category and it represents } \\
\text { simultaneous obtaining of a number of characteristics in } \\
\text { organization and public officials' activity: timeliness in } \\
\text { complying with the administrative decisions of superior } \\
\text { authorities and their officials, high quality of social } \\
\text { services provided to people, efficiency in decision-making, } \\
\text { effectiveness of the carried out activities, creation of the } \\
\text { effective system of internal and external activity control; } \\
\text { the mechanism for increasing the performing discipline of } \\
\text { public officials includes consequent improvement of the } \\
\text { above criteria. }\end{array}$ & $\begin{array}{l}\text { Timeliness (planned and } \\
\text { actually spent time) }\end{array}$ \\
\hline $\begin{array}{l}\text { Reliability and } \\
\text { relevance of the } \\
\text { administrative } \\
\text { information }\end{array}$ & $\begin{array}{l}\text { Under any circumstances, even most unfavorable ones, } \\
\text { public officials should receive timely, reliable and objective } \\
\text { information, otherwise all the processes including the } \\
\text { use of such information become more complicated; if the } \\
\text { information provided by the public officials is reliable and } \\
\text { relevant, such activity could be regarded as effective. }\end{array}$ & $\begin{array}{l}\text { The number of } \\
\text { reclamations/ } \\
\text { complaints from district } \\
\text { administrations, lower } \\
\text { organizations and other } \\
\text { organizations that } \\
\text { received information } \\
\text { from the department. } \\
\text { Customer focus index }\end{array}$ \\
\hline
\end{tabular}


analysis and development forecasting, but also for any of its employees with the possibility of making adjustments.

$R_{\text {department }}=\frac{\sum R_{\text {employee }}}{\text { the number of empoyees }}$,

where $R_{\text {department }}=$ effectiveness of the department's activity;

$\sum R_{\text {employee }}=$ overall effectiveness of all the employees activity.

In this case the department's effectiveness is considered as the degree of a goal achievement.

The analysis of an employee's activity, the purpose of his/her activity and his/her tasks and functions are also defined.

The author proposes to carry out the development of the employee's performance indicator (KPI) criteria on the basis of the technology of functions (functions; functions specification; results of functions performance; indicators characterizing the results). The results are shown in Table 4.

As an example, let us consider hypothetical work of the chief specialist of the department of analysis and development forecasting on technological regulations development for the subordinated institutions. Assume that an employee is requested to develop 19 technological regulations for the Integrated Centres for Public Service Delivery in one month (March). The calculation of the indicators characterizing the result of the employee's activity is given in Table 5 .

In this case, the employee effectiveness is regarded as the degree of a goal achievement and comprises $76.1 \%$. The calculations demonstrate low efficiency of the employee.

As we can see, one of the main mechanisms for fighting corruption is transparency of the government agencies' activity, as well as direct objective control by the means of the agencies and employees' effectiveness assessment.

\section{Conclusion}

The novelty of this approach lies in the fact that the possibility of using the methodology for assessing effectiveness of the civil servants' activity has not been previously considered

Table 4. Key indicators of the department's employee efficiency

\begin{tabular}{|l|l|l|}
\hline \multicolumn{1}{|c|}{ Functions } & \multicolumn{1}{|c|}{$\begin{array}{c}\text { Result of the functions } \\
\text { performance }\end{array}$} & \multicolumn{1}{c|}{$\begin{array}{c}\text { Indicators, characterizing } \\
\text { the result (KPI) }\end{array}$} \\
\hline $\begin{array}{l}\text { Processing of the information } \\
\text { materials coming from district } \\
\text { administrations }\end{array}$ & Information report & $\begin{array}{l}\text { Timeliness (planned and actual time } \\
\text { spent) } \\
\text { Compliance with the requirements } \\
\text { (normative acts and regulations) }\end{array}$ \\
\hline $\begin{array}{l}\text { Documentation of information and } \\
\text { analytical materials and regulatory } \\
\text { acts }\end{array}$ & $\begin{array}{l}\text { Activity reports, information } \\
\text { certificates, regulatory a3cts }\end{array}$ & $\begin{array}{l}\text { Timeliness (planned and actual time } \\
\text { spent) } \\
\text { Compliance with the requirements } \\
\text { (laws, resolutions and regulations) } \\
\text { Number of reclamations (complaints } \\
\text { from organizations) }\end{array}$ \\
\hline $\begin{array}{l}\text { Giving methodological assistance } \\
\text { and systematic consultations } \\
\text { (written and oral) on the issues of } \\
\text { social and economic development }\end{array}$ & $\begin{array}{l}\text { The number of citizens and } \\
\text { organizations that were } \\
\text { given assistance }\end{array}$ & $\begin{array}{l}\text { Timeliness (planned and actual time } \\
\text { spent) } \\
\text { Number of reclamations / complaints } \\
\text { from citizens and organizations } \\
\text { Customer focus index } \\
\text { (satisfaction of citizens and } \\
\text { organizations) }\end{array}$ \\
\hline
\end{tabular}


Table 5. Key Performance Indicators calculation

\begin{tabular}{|l|c|c|c|c|}
\hline \multicolumn{1}{|c|}{ KPI } & Significance, \% & Plan & Fact & Result \\
\hline Timeliness (days) & 30 & 22 & 34 & 19,4 \\
\hline Compliance with the requirements (\%) & 25 & 100 & 100 & 25 \\
\hline The number of reclamations (complains) (number) & 20 & - & 4 & 0 \\
\hline Customer satisfaction index (proportion) & 25 & 1 & 0,789 & 31,7 \\
\hline & 100 & & Total R & 76,1 \\
\hline
\end{tabular}

in the doctrine as a deterrent factor of corrupt activities.

The positive effect of the KPI system implementation is determined by increase in overall effectiveness of the Committee activity, since with the use of this system every employee of the Committee realizes the connection between their direct responsibilities and the strategic objectives of the Committee. With the use of decision making support mechanism, the managers have the ability to measure effectiveness of each employee's activity and, accordingly, the activity of the department as a whole, and can influence the process of the Committee's strategy implementation.

In the author's opinion, strengthening of control over activity, increased responsibility to the citizens, strict accountability and application of the new methods of performance assessment of not only the body as a whole, but each employee as well, could be able to reduce the level of corrupt activity in government agencies.

\section{References}

Andreeva, D.A. (2015). Otsenka effektivnosti deiatel'nosti gosudarstvennykh grazhdanskihk sluzhashchikh [Civil Servants' Performance Assessment]: dissertation for the degree of candidate of economic sciences: 08.00.05 / Andreeva Daria Andreevna; [Place of presentation: Saint Petersburg State University of Economics], Saint Petersburg, 135 p.

Based on the research of experience of 15 countries, the methodology for assessing the institutional environment of civil service was introduced: Manning, N., Mukherjee, R. and Gokcekus, O. (2000). Public Officials and Their Institutional Environment: An analytical Model for Assessing the Impact of Institutional Changes. World Bank, available at: http://dx.doi.org/10.1596/1813-9450-2427

Broadman, H.G., Recanatini, F. (2000) Seeds of Corruption: Do Market Institutions Matter? World Bank. Europe and Central Asia Region. World Bank. Poverty Reduction and Economic Management. In Policy Research Working Papers, 2368

Klochkov, A. (2010). KPI i motivatsiia personala. Polnyi sbornik prakticheskikh instrumentov [KPI and Employee Motivation. The Complete Collection of Practical Tools]. ISBN 978-5-699-379019, M, EKSMO, 164 p.

Korruptsionnye prestupleniia [Corrupt Crimes]. Official website of the Investigative Committee of the Russian Federation, available at: http://sledcom.ru/news?type=corrupt (accessed 10 November 2015).

Kaufmann, D., Kraay, A., Mastruzzi, M. (2005). Governance matters IV: Governance Indicators For 1996-2004. In Journal: SSRN Electronic Journal, DOI: 10.2139/ssrn.718081. 
Kholostova, E.I. (2013). Sotsial'naia politika i sotsial'naia rabota [Social Policy and Social Work]. $4^{\text {th }}$ edition, revised and complemented, M, Publishing and Trading Corporation "Dashkov \& Co", 208 p.

Metodika otsenki effektivnosti deiatel'nosti organov ispolnitel'noi vlasti sub"ektov Rossiiskoi Federatsii [Procedure for Assessing the Performance of Executive Authorities of the Subjects of the Russian Federation]. Approved by the Decree of the Government of the Russian Federation dated 3 November 2012 No. 1142. Available at: http://docs.cntd.ru/document/902378408 (accessed 07 October 2015).

Polozhenie o provedenii attestatsii gosudarstvennukh grazhdanskikh sluzhashchikh Rossiiskoi Federatsii [Statute on Conducting Performance Review of the Civil Servants of the Russian Federation]. Decree of the President of the Russian Federation dated 1 February 2005, No. 110 In Rossiyskaya Gazeta, Federal Issue No. 3689, 3 February 2005.

Parmenter, D. (2007). Key Performance Indicators: Developing, Implementing and Using Winning KPI's. New Jersey, USA, John Wiley \& Sons, inc., ISBN 0-470-09588-1.

\title{
Отдельные показатели эффективности деятельности органов государственной власти как элемент механизма противодействия коррупции
}

\author{
А.Д. Андреева \\ Международный банковский институт \\ Россия, 191023, Санкт-Петербург, Невский проспект, 60
}

В работе представлен анализ методики оценки эффективности деятельности органов исполнительной власти РФ на примере деятельности Комитета по сочиальной политике 2. Санкт-Петербурга. Предложенные автором ключевые показатели эффективности деятельности государственных служащих Комитета по социальной политике г. СанктПетербурга позволяют оценить эффективность деятельности государственного служащего. Рассматривается перспектива применения выменазванной методики в качестве одного из методов противодействия коррупции в данных органах.

Ключевые слова: государственный служащий, коррупщия, ключевые показатели эффективности.

Научная специальность: 08.00.00 - экономические науки. 